\title{
PERBEDAAN SIKAP KEBERAGAMAAN ANTARA MASYARAKAT ISLAM DAN KRISTIANI DI SUMATERA UTARA DAN FRANKFURT AM MAIN JERMAN
}

\author{
Irwansyah \\ Universitas Islam Negeri Sumatera Utara Medan, Indonesia \\ E-mail: irw.betawi@yahoo.co.id
}

\begin{abstract}
This article seeks to reveal differences of religious attitudes between Muslim and Christian communities in North Sumatera and Frankfurt Am Main Germany. This article shows that the relation between Muslims and Christians can be understood to have taken place in two categories, positive and negative. Positive relation can be attested through integrating factors between the two religious communities, while negative relation can be attested through separating factors. In North Sumatera there exist local wisdoms which serve as adhesive factors of MuslimChristian relation, such as the concept of "marga" among Batakese society. Meanwhile, pig either as food or as pet is regarded as a dividing factor together with fanaticism and exclusivism. In Germany, as majority group the Christians are tolerant towards Muslims due to the rule of law in the country. This tolerance becomes an adhesive factor, while mutual suspicion among both Muslims and Christians is raeagrded as dividing factor.
\end{abstract}

Keywords: Social relations; Muslims; Christians; adhesive and dividing factors.

\section{Pendahuluan}

Tema dalam tulisan ini dipilih karena tiga alasan: pertama didasari oleh penelitian Disertasi berjudul: Hubungan Muslim-Kristiani di Sumatera Utara yang sedang ditulis, kedua didasari oleh bahwa Jerman adalah tempat di mana Kristiani (Protestan) lahir, dan ketiga karena alasan penelitian "Doktor" di Goethe Universitat, Frankfurt-Jerman, dari tanggal 20 September s/d 19 Oktober 2013.

Penelitian "Doktor" di Goethe Universitat, Frankfurt-Jerman selama satu bulan, atas bimbingan Arndt Graf, Guru Besar dalam bidang Sejarah dan Kebudayaan Asia Tenggara; Kepala di 
Departemen of Southeast Asian Studies di Goethe Universitat Frankfurt am Main, Jerman. Beliau mengungkapkan bahwa "Perpustakaan" yang tersedia di Goethe Universitat, tentang Indonesia, pada umumnya mengenai Indonesia zaman modern, yakni setelah kemerdekaan. Khusus mengenai hubungan antar-agama di Indonesia, didapati literatur yang ditulis oleh orang Indonesia, pada tahun 1960-an misalnya karya M. Natsir berjudul: Islam dan Kristen di Indonesia (Bandung: Peladjar dan Bulan Sabit, 1969). Sungguhpun buku tersebut dicetak pada tahun 1969, akan tetapi tema dan permasalahan yang terdapat di dalam buku itu adalah problema hubungan antar-agama di Indonesia, sebelum kemerdekaan.

Beberapa tema yang ditulis M. Natsir: "Kristen di Belakang Pemerintah", "Zending Contra Islam", "Islam, Katholik, Pemerintah", "Suara Adzan dan Lontjeng Geredja: 'Islam' dalam Konferensi Zending", "Perpisahan Geredja dan Keradjaan”, "Urusan Hinaan atas Islam", "Islam Berantas Intoleransi Agama dan Tegakkan Kemerdekaan Beragama”. "Keragaman Hidup Antar-agama", "Kode Toleransi Beragama", dan lain-lain. Selanjutnya dalam buku tersebut dilampirkan Pidato Sambutan Pejabat Presiden Republik Indonesia pada Pembukaan Musyawarah Antar-agama, Pidato Pembukaan Musyawarah Antar-golongan Agama oleh Menteri Agama K.H.M. Dachlan, Pidato Sambutan Dr. H.M. Rasjidi dan lainnya.

Tema-tema yang ditulis oleh M. Natsir dalam buku tersebut adalah fenomena keberagamaan bangsa Indonesia sebelum Kemerdekaan, akan tetapi "persoalan" hubungan antar-agama terutama hubungan antara umat Muslim dengan Kristiani justru berlanjut sampai pada masa awal kemerdekaan, bahkan sampai pada masa Orde Baru dan juga sampai saat penelitian ini dilakukan. Namun demikian penelitian ini tidak bermaksud ingin menjelaskan bagaimana hubungan Muslim-Kristiani dari masa ke masa, dan bukan pula ingin mengungkapkan tentang bagaimana fenomena keberagamaan secara luas dan mendalam, akan tetapi ingin memeroleh beberapa informasi mengenai bagaimana hubungan Muslim dan Kristiani khusus menyangkut beberapa faktor yang dapat dikelompokkan kepada "faktor perekat" dan "faktor pemisah" antara Muslim dan Kristiani.

Muslim adalah istilah yang dipakai untuk masyarakat penganut agama Islam, tanpa dibedakan kelompok dan aliran serta organisasi massa yang ada, termasuk juga aliran yang di Indonesia dikatakan "sesat" dan keluar dari Islam oleh Majelis Ulama Indonesia (MUI), 
namun di Jerman dihitung sebagai Muslim yang sukses dan berhubungan baik dengan Kristiani.

Istilah "Kristiani" yang dipakai untuk mengungkapkan masyarakat Kristen Protestan dan Kristen Katolik, di Jerman justru memang demikian yang diterapkan. Salah seorang penganut Katolik di Jerman, ${ }^{1}$ justru merasa heran ketika dikatakan padanya bahwa di Sumatera Utara sebutan "Kristen" biasa untuk menyebut "Kristen Protestan", sedangkan penganut Katolik, lebih senang tidak disebut sebagai "Kristen". 2

Penelitian ini adalah penelitian lapangan dengan menggunakan prosedur kualitatif, antara lain menaati asas tanpa menentukan populasi dan sample, tidak mengandaikan sebuah hepotesa sehingga tidak membutuhkan pengujian terhadapnya. Sebagai gantinya hanya menetapkan fokus penelitian yakni mengandaikan bahwa telah terjadi "hubungan" (interaksi) antara masyarakat Muslim dengan masyarakat Kristiani, baik itu di berbagai tempat di Sumatera Utara maupun di Frankfurt am Main, Jerman; yang dilakukan dengan cara mendeskripsikan fenomena yang ada dan yang terjadi dalam hubungan dimaksud.

Tulisan ini merupakan ungkapan deskriptif tentang hasil diskusi, dialog, wawancara dan pengamatan tentang fenomena keberagamaan masyarakat Muslim dan Kristiani di Frankfurt, lalu dikomparasikan dengan fenomena keberagamaan di Sumatera Utara, atau sebaliknya bahwa fenomena keberagamaan di Sumatera Utara dikomparasikan dengan fenomena keberagamaan di Frankfurt am Main, Jerman.

\section{Hubungan Muslim-Kristiani di Sumatera Utara}

Hubungan masyarakat Muslim dan Kristiani di Sumatera Utara sudah terjadi sejak lama, yakni sebelum "Indonesia" merdeka. Masyarakat Islam dan masyarakat Kristen di Sumatera Utara telah berdampingan dan hidup bersama diduga sejak datangnya agama Kristen ke Tanah Batak pada abad ke 19; karena agama Islam telah lebih dulu ada di sana beberapa abad sebelum datangnya agama

\footnotetext{
${ }^{1}$ Daniel Balondo, Wawancara, Toraja 25 September 2013.

${ }^{2}$ Kasus Pastor Beno Ola Tage, salah seorang Pastor di Keuskupan Agung Medan yang kini sudah pindah tugas ke Filipina, pernah menunjukkan Kartu Tanda Penduduk (KTP), yang masih membuat agama Kristen adalah agama yang dianutnya. Ia kecewa dengan pendataan kependudukan di Indonesia, padahal menurut beliau "Katolik" adalah agama yang berbeda dan diakui sama dengan "Protestan", semestinya, menurut beliau umat Katolik, di KTP tertulis "Katolik" bukan "Kristen".
} 
Kristen. Jauh sebelum Injil diberitakan di Tanah Batak, daerah ini sudah lebih dulu dimasuki Islam, terutama pada beberapa kawasan di bagian Utara (Karo), Timur (Simalungun), Selatan (Mandailing dan Angkola) dan Barat (memanjang dari Natal di Selatan, Sibolga, hingga ke Barus dan Singkel di Utara). ${ }^{3}$

Khusus di daerah Karo dan Simalungun Islam sudah masuk melalui interaksi masyarakat Batak yang ada di sana dengan saudarasaudaranya masyarakat Melayu yang ada di daerah Langkat, Deli Serdang, dan Asahan yang sudah menganut agama Islam sejak abad ke 13. ${ }^{4}$ Bahkan orang Karo dan Simalungun, justru mengaku menjadi orang "Melayu" setelah masuk Islam. ${ }^{5}$

Akan tetapi menurut catatan beberapa penulis, ${ }^{6}$ bahwa Islam masuk di Simalungun dimulai dengan pengislaman beberapa kerajaan sejak abad ke 15, terutama atas dukungan Sultan Malaka, Sultan Mansyur Sjah sekitar tahun 1450 dan didukung pula oleh ekspansi kesultanan Aceh ke Simalungun sejak tahun 1539. Akan tetapi penyebaran Islam yang lebih intensif baru sejak akhir abad ke 19 dan awal abad ke 20, ketika Raja Siantar masuk Islam tahun $1901 .{ }^{7}$

Jumlah penduduk Sumatera Utara 12.967.655 jiwa dengan perincian 64,70\% beragama Islam, 27,04\% beragama Kristen, dan $5,20 \%$ beragama Katolik yang tersebar di 28 kabupaten/kota. ${ }^{8}$ Beberapa daerah komposisi pemeluk agamanya tidak seimbang, ada mayoritas dan adapula minoritas, ${ }^{9}$ tetapi adapula yang seimbang atau

${ }^{3}$ Jan S. Aritonang, Sejarah Perjumpaan Kristen dan Islam di Indonesia (Jakarta: BPK Gunung Mulia, Cet. Ke-3 2006), 102.

${ }^{4}$ Ibid., 103.

5 J.R. Hutauruk, Kemandirian Gereja (Jakarta: BPK Gunung Mulia, 1992), 13. Bandingkan dengan analisis peneliti dalam Irwansyah, "Interaksi Sosial MuslimKristiani di Sumatera Utara: Studi tentang Hubungan Keduanya di Pemukiman", Tsaqafah: Jurnal Peradaban Islam, Vol. 10, No. 2 (2014).

6 Catatan tersebut antara lain: Dada Meuraxa, Sejarah Kebudayaan Suku-suku di Sumatera Utara (Medan: Sasterawan, 1973); Kenan Purba dan J.D. Purba, Sejarah Simalungun (Jakarta: Bina Budaya Simalungun, 1995); Williem Marsden, Sejarah Sumatera (Bandung: Remaja Rosdakarya, 1999); Juandaha RP. Dasuha, Sejarah Seratus Tahun Pekabaran Injil di Simalungun, 3 September 1903-2003 (P. Siantar: Kolportase GKPS dll., 2003).

${ }^{7}$ Aritonang, Sejarah Perjumpaan, 103.

${ }^{8}$ Data Rekapitulasi Penduduk Menurut Agama. Diolah dari data statistik BPS Pusat tahun 2010.

9 Penduduk yang mayoritas beragama Islam, minoritas Kristen dan Katolik adalah Mandailing Natal $(97,39 \%, 2,25 \%, 0,34 \%)$, Padang Lawas Utara $(94,69 \%, 5,27 \%$, 0,04\%), Langkat $(90,00 \%, 7,56 \%, 1,06 \%)$, Asahan $(87,93 \%, 9,4 \%, 1,03 \%)$, 
hampir sama komposisi jumlah pemeluknya. ${ }^{10}$ Akan tetapi belum ada data yang menunjukkan sebaran suku apa saja yang memeluk agama Islam, Kristen maupun Katolik dari belasan suku yang terdapat di Sumatera Utara. Ungkapan bahwa "Melayu" sama dengan "Islam" dan "Batak" sama dengan "Kristen" bukanlah menggambarkan "jumlah" dan bukan pula dalam arti yang sungguh-sungguh terjadi sampai saat ini, hanya merupakan stereotype yang bahkan membuat sebagian suku Batak seperti masyarakat Angkola, Mandailing, dan Padang Lawas yang bermukim di Medan merasa kurang senang bilamana dikelompokkan sebagai etnis Batak. ${ }^{11}$

Akan tetapi di beberapa daerah di "Tanah Batak" (di Kabupaten Simalungun), didapati suatu kampung yang diberi nama "Kampung Melayu", dan justru di Kampung tersebut tidak didapati satu orang pun "suku/etnis Melayu", mereka adalah "orang Batak" yang beragama Islam, berada di tengah-tengah masyarakat Kristiani yang juga "orang Batak". Istilah "Melayu" dan "Batak" menjadi menarik dan menjadi perhatian serius dalam membicarakan hubungan Muslim dan Kristiani di Sumatera Utara. Betapa tidak, karena ketika I.L.Nommensen (1834-1918) ${ }^{12}$ berhasil “meng-kristen-kan" orang

Batubara $(86,18 \%, 9,39 \%, 1,81 \%)$, Tapsel $(85,37 \%, 13,68 \%, 0,94 \%)$, Binjai $(85,11 \%$, 6,89\%, 1,66\%), Labuhan Batu (83,71\%, 13,08\%, 2,10\%), Tanjung Balai $(81,99 \%$, $7,78 \%, 1,06 \%)$, Sergei $(81,58 \%, 13,17 \%, 3,16 \%)$, Padang Lawas $(80,55 \%, 12,35 \%$, $7,09 \%)$, Deli Serdang $(79,59 \%, 15,10 \%, 3,00 \%)$, Tebing Tinggi $(77,47 \%, 11,47 \%$, $1,78 \%)$, Padang Sidempuan $(75,39 \%, 23,71 \%, 0,53)$, dan Medan $(67,83 \%, 18,13 \%$, $2,89 \%)$.

Penduduk yang mayoritas beragama Kristen dan Katolik, minoritas Islam adalah Tapanuli Utara $(87,32 \%+8,63 \%, 3,90 \%)$, Nias $(84,03 \%+10,30 \%, 5,43 \%)$, Humbang Hasundutan $(78,28 \%+16,50 \%, 5,22 \%)$, Samosir $(59,15 \%+38,95 \%$, 1,85\%), Toba Samosir $(72,95 \%+23,21 \%, 3,15 \%)$, Nias Selatan $(75,97 \%+21,21 \%$ , 2,58\%), Dairi $(71,30 \%+11,25 \%, 17,16 \%)$ dan Karo $(57,69 \%+16,67 \%, 24,06 \%)$.

10 Penduduk yang seimbang atau hampir sama jumlahnya antara yang beragama Islam dengan yang beragama Kristen ditambah Katolik adalah Sibolga (58,47\%, $32,36 \%+5,21 \%)$, Simalungun $(58,40 \%, 35,30 \%+5,81 \%)$, Pakpak Barat $(45,42 \%$, $52,21 \%+2,37 \%)$, Pematang Siantar $(42,86 \%, 45,14 \%+5,06 \%)$, dan Tapteng $(42,25 \%, 43,93 \%+13,34 \%)$.

11 Subanindyo Hadiluwih, Konflik Etnis di Indonesia: Suatu Kajian Kes di Bandaraya Medan (Medan: USU Press, 2008), vii.

12 Ingwer Ludwig Nommensen lahir 6 Februari 1834 di pulau kecil Marsch (pantai Utara Jerman berbatasan dengan wilayah Denmark) di Nordstrand, di daerah Schleswig-Holstein. Pendeta Ingwer Ludwig Nommensen datang ke Sumatera Utara dan bergabung dengan Van Asselt, Betz, Klammer dan Heine di Parausorat Sipirok, tahun 1862. (14 Mei 1862 Nommensen sampai di Padang, 23 Juni 1862 sampai di 
Batak (di daerah Tapanuli bagian Utara), lalu orang Batak yang telah menjadi Kristen, "turun Gunung" ke "Tanah Deli" kampungnya "orang Melayu", maka terjadilah "hubungan" antara masyarakat Kristiani dan masyarakat Islam.

Sejarah masa lalu hubungan kedua komunitas (Muslim-Kristiani) di Sumatera Utara turut memengaruhi keadaan dan suasana serta eksistensi hubungan sosial yang terjadi saat mencari penghidupan ekonomi, dengan cara menggarap sawah dan membuka lahan pertanian di daerah-daerah pemukiman kamunitas Muslim, atau para Sultan kerajaan "Deli" yang memerluas kekuasaannya sampai ke "tanah Batak", membawa missi Islam; ternyata sampai sekarang masih menyisakan "sesuatu" yang dapat dijadikan indikator yang memengaruhi hubungan Muslim-Kristiani saat ini.

Masyarakat Sumatera Utara, dikenal sebagai masyarakat yang tingkat heterogenitasnya tinggi, akan tetapi justru "dianggap" paling rukun. Mantan Presiden RI. Susilo Bambang Yudoyono dalam pidatonya pernah mengatakan bahwa daerah Sumatera Utara adalah "Barometer Kerukunan Umat Beragama" di Indonesia. Demikian juga, jika ditanyakan kepada masyarakat, apakah umat beragama hidup rukun? Mereka menjawab tanpa ragu-ragu dan meyakinkan bahwa mereka hidup rukun dan damai. Jika mereka ditanya bagaimana hubungan masyarakat Muslim dengan masyarakat Kristiani, mereka menjawab tidak ada masalah. Sebagian menjawabnya dengan mengemukakan fakta bahwa dalam keluarga mereka ada keluarga yang beragama Kristiani dan sebagian yang lain beragama Islam, sedangkan mereka tinggal dalam satu rumah. Salah seorang Pendeta dan penganut Kristiani yang taat malah didapati sebagian keluarganya justru memeluk agama Islam. Akan tetapi fenomena seperti ini terjadi dalam masyarakat etnis Batak, yang Kristiani terutama apabila "keislaman" mereka terhitung masih "muallaf" (mereka baru memeluk Islam atau pengetahuan dan keimanannya terhadap Islam terhitung "rendah").

Hidup bersama satu keluarga antara penganut Kristiani dan penganut Muslim tidak didapati di kalangan masyarakat etnis Melayu

Sibolga dan tiba di Barus 25 Juni 1862). Bulan Mei 1964 Nommensen memulai missinya di Silindung, sebuah lembah yang subur di daerah Tapanuli, dikelilingi bukit dan gunung nan hijau, diapit oleh Bukit Siatas Barita di sebelah Timur dan Gunung Martimbang di sebelah Barat, dialiri dua sungai yaitu Sungai Sigeaon da Sungai Situmandi yang menjadi satu di daerah Husor menjadi Sungai Batang Toru. 
dan dalam masyarakat Muslim, di mana keberislaman sudah terhitung baik. Salah satu penyebab mengapa keluarga mereka yang sudah menjadi Muslim tidak dapat tinggal dan hidup bersama dengan keluarga mereka yang Kristiani adalah adanya pantangan makan daging babi bagi seorang Muslim.

Bukan hanya hidup satu rumah dalam satu keluarga, bahkan hidup berjiran dan bertetangga pun menjadi terhalang karena babi. Sebagian masyarakat Muslim, berkeyakinan bukan hanya memakannya saja yang dilarang, akan tetapi segala sesuatu yang terkait dengan babi pun tidak boleh disentuh. Ada kasus di daerah Karo, seorang saudaranya yang menjadi Muslim justru tidak mau lagi berjabat tangan, sentuhan tangan tanpa lapis, karena dianggap tangan saudaranya yang Kristiani telah bersentuhan dengan babi. Fenomena seperti ini mungkin sebuah kasuistis, akan tetapi babi telah menjadi isu yang selama ini memisahkan antara Muslim dengan Kristiani. Salah seorang pendeta senior A. Ginting Suka mengungkapkan bahwa dulu pada tahun 1950an menjadi Muslim bagi kami orang Karo sama dengan kehilangan saudara; karena setelah menjadi Muslim tidak lagi mau datang ke rumah dan sepertinya tidak bersaudara lagi, itu karena kami memasak dan memakan daging babi.

Lebih jauh, mengenai hewan yang satu ini, bukan hanya ketika menjadi makanan ia mempunyai daya kuat yang memisahkan persaudaraan Muslim-Kristiani, akan tetapi memeliharanya juga mengakibatkan perselisihan yang berkepanjangan dan menjadi fenomena yang meretas hubungan harmonis antara masyarakat Islam dengan masyarakat Kristiani.

Sepanjang penelitian tentang faktor perekat dan faktor pemisah hubungan antara masyarakat Muslim dengan masyarakat Kristiani di Sumatera Utara, kasus memelihara atau berternak babi, bukan hanya sebagai pemisah hubungan, akan tetapi malah dalam beberapa kasus justru dijadikan alat oleh sebagian masyarakat Kristiani untuk menguasai daerah atau tempat tertentu, ketika mereka (orang Batak yang Kristiani) turun gunung dan mulai bertempat tinggal di daerah pemukiman yang sebelumnya lebih dulu menjadi tempat pemukiman masyarakat Islam. Kasus masa lalu seperti ini, di berbagai daerah Sumatera Utara masih menyisakan perasaan yang kurang menyenangkan di kalangan masyarakat Muslim terhadap masyarakat Kristiani, sehingga kalaupun masyarakat Muslim masih bertahan di kampungnya, karena sebagian telah ditempati oleh masyarakat 
Kristiani, mereka hidup terpisah, mengelompok dan berkerumun sesama masyarakat Muslim. Terkadang mereka hanya dipisahkan oleh sebuah jalan utama, gang, kompleks perumahan dan bahkan terkadang mereka membangun sebuah dusun atau kampung sendiri. Keadaan seperti ini tidak jarang juga menimbulkan perselisihan antarkampung, bila terjadi sedikit saja perselisihan di antara warga. Dalam beberapa kasus perselisihan yang terjadi, penyebabnya justru bukan karena persoalan agama, tetapi persoalan lain, misalnya kasus pergaulan anak muda, kasus kecelakaan lalu lintas, dan kasus sosial lainnya, di mana kasus tersebut melibatkan sentimen keagamaan, sehingga terjadilah perang antar-kampung.

Kasus perang antar-kampung yang melibatkan masyarakat Muslim dan Kristiani ini terjadi puluhan tahun yang lalu, sekira tahun 1960-an dan 1970-an. Masyarakat Muslim dan Kristiani yang dulunya pernah terlibat konflik itu kini sudah berdamai, saling menahan diri, dan mereka tinggal bersebelahan kampung yang terkadang tanpa kontak dan boleh dikatakan tidak terjadi hubungan sosial antara mereka. Rasa saling curiga masih terlihat, rasa takut, dan trauma terhadap peristiwa masa lalu pun masih ada, ketika penelitian ini dilakukan.

Di beberapa daerah mereka justru hidup membaur. Hal ini mengindikasikan terjadinya keakraban dan kedekatan antara masyarakat Muslim dan Kristiani. Sekali lagi, tidak memelihara ternak babi bagi masyarakat Kristiani adalah peluang bahkan dapat dijadikan perekat hubungan sosial dengan masyarakat Muslim. Sebutlah Sipirok misalnya, sebuah kecamatan di kabupaten Tapanuli Selatan yang selama ini selalu dijadikan potret ideal kerukunan umat beragama di Sumatera Utara, bahkan di Indonesia. Di sana masyarakat Muslim dan Kristiani hidup membaur, bersaudara, dan sangat akrab. Mereka saling mengunjungi dalam hari-hari besar keagamaan, yang Muslim makan di rumah saudara mereka yang Kristiani, dan masyarakat Kristiani bergotong royong memberi bantuan membangun rumah ibadah masyarakat Muslim dan sebaliknya. Hampir semua peneliti kagum dengan pola kerukunan yang terbangun sudah sejak nenek moyang mereka di Sipirok.

Akan tetapi satu hal yang dilupakan, atau sengaja tidak diungkapkan oleh para peneliti kerukunan, bahwa mengapa mereka dapat hidup membaur dalam harmoni seperti itu? Salah satu sebab utamanya adalah karena di Sipirok ada satu kearifan lokal yang terpelihara, yaitu mereka yang beragama Kristiani tidak memelihara 
ternak babi. ${ }^{13}$ Hewan babi bukan hanya tidak dipelihara, akan tetapi demi menghormati saudara mereka yang Muslim, mereka tidak memakannya. Pesta adat yang bagi masyarakat Batak pada umumnya menggunakan daging babi sebagai hidangan (jambar), di Sipirok digantikan dengan daging kerbau. ${ }^{14}$

\section{Fenomena Keberagamaan Frankfurt am Main}

Jerman adalah negara sekuler ${ }^{15}$ yang maju dan berkembang di Eropa sudah ratusan tahun yang lalu. Akan tetapi agama mendapat perhatian yang serius dari negara. Negara memandang dan menempatkan semua rakyat sama dalam pandangan konstitusi. Apakah masyarakat itu beragama atau tidak menganut agama. Namun karena Martin Luther lahir di Jerman dan melakukan pembaruan terhadap agama Kristen, maka agama Kristen versi Lutheranisme

13 Larangan memelihara dan memakan daging babi di Sipirok,berasal dari orang bijak bernama Djarumahot Nasution. Sampai saat ini di daerah Parausorat tidak ada masyarakat yang memelihara ternak babi, karena masyarakat selalu mengenang dan mematuhi larangan tersebut demi terciptanya hubungan baik antara Muslim dan Kristiani. Oleh masyarakat Parausorat Sipirok, Djarumahot dipandang sebagai tokoh atau bapak kerukunan (terutama antara umat Islam dan umat Masehi, sebutan yang santun untuk umat Kristen di desa Parau Sorat, Tapanuli Selatan) karena berhasil memersatukan Muslim dan Kristiani melalui keluarganya. Djarumahot adalah nama lain dari Hoesni Nasution, anak dari Idris Nasution (Tuanku Lelo). Idris Nasution adalah salah seorang panglima perang Tuanku Imam Bonjol. Beliau pernah melakukan pengislaman di tanah Batak bersama Tuaku Rao (Pongki Nangolngolan Sinambela) sekitar tahun 1816-1820. Djarumahot mempunyai enam orang anak, tiga orang sebagai Muslim dan tiga orang lagi Kristiani. Salah seorang putranya yang Muslim menjadi khalîfah (gelar tertinggi yang diberikan dalam kelompok tarekat dalam Islam), sedangkan salah seorang putra Djarumahot yang Kristiani, berhasil menjadi pendeta, yang dikenal dengan nama Pdt. Petrus Nasution.

${ }^{14}$ Fenomena yang terkait dengan mengganti makanan adat babi dengan kerbau atau ayam selama ini dilakukan oleh umat Kristini untuk menghargai dan menghormati saudara mereka yang Muslim dalam suatu upacara adat, misalnya dalam upacara perkawinan dan upacara kematian.

15 Suratno, Wawancara, Goethe Universitat, Frankfurt Jerman 13 Oktober 2013. Suratno menjelaskan bahwa mengenai negara sekuler, ada black scular dan ada white scular dan negara Jerman menganut white scular. Akan tetapi menurut Prof. Dr. Arndt Graf, bahwa Jerman "bukan" negara sekuler, karena secara de facto yang memerintah di Jerman adalah penganut Kristen Protestan dan terdapat sistem yang namanya "Pajak Gereja". Akan tetapi Arndt Graf mengatakan bahwa negara Jerman saat ini sedang memerhatikan "agama"; mulai bulan Oktober 2013 ini, Konstitusi Pendidikan Jerman menerima agama Islam masuk dalam kurikulum pendidikan di seluruh Jerman. Arndt Graf, Wawancara, Uni-Western, Frankfurt 30 September 2013. 
tentu menempati posisi strategis, apalagi jika dikaitkan dengan tesis Max Weber (1864-1920) yang menghubungkan kebangkitan kapitalisme Eropa dengan Agama Protestan.

Pengaruh tesis Max Weber tersebut hingga kini masih terlihat, bahkan diakui pula oleh mereka yang tidak beragama Kristen Protestan. Di Frankfurt Jerman, misalnya, tepatnya di sebuah gedung yang dulunya adalah sebuah Gereja Katolik yang berada di tengah kota Frankfurt kini menjadi Gedung terhormat, untuk memberikan Hadiah Nobel Perdamaian bagi para ahli yang berprestasi. Sejak tahun 1950 sampai 2012, dari sekian banyak yang mendapat hadiah nobel mulai Max Tau sampai Liao Yiwu, 80\% di antaranya adalah dari kalangan Kristen Protestan dan 20\% tersisa dari Yahudi. Sementara itu yang beragama Katolik dan lainnya tidak didapati informasi pernah mendapat penghargaan terhormat itu. Salah satu fenomena inilah yang kemudian dapat dijadikan bukti bahwa tesis Max Weber memang mempunyai pengaruh yang signifikan, bahwa kebangkitan kapitalisme Eropa dipengaruhi oleh etika Protestan yang pada gilirannya memberikan mereka posisi-posisi strategis. ${ }^{16}$

Dari sekira 82 juta jiwa penduduk Jerman, 52 juta adalah beragama Kristiani dan Islam ditaksir sekitar 4.3 juta jiwa. 30 persen penduduk Jerman tidak menganut agama apa pun. Menurut informasi yang bersumber dari mahasiswa Indonesia program Doktor (S-3) di Jerman, sebenarnya masyarakat Jerman terutama yang Kristiani tidak bersikap toleran terhadap umat Islam di Jerman. Karena kekuatan konstitusi yang berkeadilan, hal itu menjadikan hubungan umat Kristiani dan Muslim menjadi (harus) baik. ${ }^{17}$

Belakangan ini, ada kecenderungan yang mengarah kepada hal yang sangat positif dari pemerintah Jerman terhadap masyarakat Muslim yang ada di Jerman. Sejak tahun 2008 pemerintah Jerman mempunyai program mencari 2000 guru agama Islam yang dapat mengajarkan Islam di sekolah-sekolah sejak tingkat sekolah dasar sampai perguruan tinggi. Sejak bulan Oktober 2013 ini, mata pelajaran agama Islam dimasukkan ke dalam kurikulum pendidikan di beberapa negara bagian di Jerman, termasuk di Frankfurt.

\footnotetext{
16 Bern, Wawancara, Bruchkobel, Jerman 5 Oktober 2013. Dia memberikan penilaian bahwa pengaruh Kekeristenan (Protestan) cukup dominan dalam kemajuan ekonomi dan keilmuan.

17 Suratno (Pengurus NU Jerman), Wawancara, Eschborn, Frankfurt 6 Oktober 2013.
} 
Beberapa hal yang dapat dijadikan indikator perekat hubungan Kristiani (yang diwakili Negara) dengan umat Islam di Jerman antara lain adalah kebijakan politik, di mana saat ini umat Islam yang didominasi oleh bangsa Turki yang sudah lama bermukim di Jerman, sekira 2.5 juta (dari 4.3 juta Muslim di Jerman), sudah ada yang masuk menjadi anggota parlemen di Jerman. Walaupun jumlahnya tidak terlalu signifikan karena hanya 11 orang dari 600 orang parlemen di Jerman, akan tetapi hal ini sudah memerlihatkan bahwa harmonisasi hubungan Muslim dengan Kristiani di Jerman berproses ke arah yang lebih baik. ${ }^{18}$

Umat Islam di Jerman berasal dari berbagai daerah seperti dari Turki, India, Arab, Maroko, Afganistan dan lain sebagainya. Akan tetapi terbanyak berasal dari Turki. Menurut Suratno bahwa hubungan Jerman dengan Turki sangat baik sekali, karena setelah Perang Dunia II, Turki membantu Jerman dalam membangun infrastruktur dengan cara menyediakan tenaga kerja di Jerman. Walaupun Jerman bukan negara Kristen, akan tetapi umat Kristen terwakili secara mayoritas dalam pemerintahan. Dalam batas tertentu hubungan Jerman dengan Turki adalah bentuk lain dari hubungan keagamaan yang terjadi secara alamiah karena hubungan kerja dan bisnis.

Umat Islam, bebas beribadah sesuka hati dan demikian juga membangun rumah ibadah juga tidak ada regulasinya seperti yang ada di Indonesia, bahkan beberapa buah bangunan yang sebelumnya digunakan sebagai gereja, kini telah dibeli oleh umat Islam dan dijadikan sebuah masjid. Secara psikologis, hal seperti ini turut membantu terciptanya hubungan yang baik antara Muslim dengan Kritiani. Namun demikian, menurut Suratno, beberapa aliran dan pemahaman umat Islam yang cenderung radikal seperti pemahaman kelompok Hizbut Tahrir tentang kbilafah yang melahirkan pergerakan dan menimbulkan kegelisahan sebagian masyarakat telah dibubarkan oleh pemerintah. Demikian juga kelompok Salafi dan bahkan kelompok Islam Turki yang ditengarai ada kaitannya dengan Osama bin Laden langsung dibubarkan oleh pemerintah. Hal ini sama sekali tidak terkait dengan hubungan Muslim-Kristiani, akan tetapi menyangkut soal hubungan agama dengan negara, demikian ungkap Suratno, yang dipercaya sebagai pengurus cabang Nahdlatul Ulama di Jerman.

${ }^{18}$ Suratno, Wawancara, Trier, Jerman 8 Oktober 2013. 
Akan tetapi ketika Suratno menjelaskan bahwa ada kepentingan bersama yang dapat dijadikan perekat antarumat beragama di Jerman, misalnya dalam bidang olah raga; keahlian main sepak bola, orang Islam Turki, Mesir, Tunisia dan Maroko yang 10 tahun terakhir ikut dalam tim nasional sepakbola Jerman. Hal ini dapat dijadikan simbol perekat - atau meminjam istilah Suratno-simbol pembauran antara Muslim dengan pemerintah Jerman yang notabene Kristiani.

Sementara itu dalam beberapa negara bagian di Jerman, diakui bahwa Islam adalah merupakan bagian dari Jerman. Suratno menambahkan bahwa pembauran juga telah terlihat dalam bidang pendidikan; bahwa Islamweisenshaft (Islamic Studies) diajarkan di tingkat perguruan tinggi di delapan tempat di Jerman, seperti di Hessen, Berlin, Tubingen, Marburg, dan lain sebagainya. Demikian juga di tingkat sekolah dasar dan sekolah menengah Islam sudah diajarkan dan secara resmi oleh pemerintah mulai masuk dalam kurikulum pada tahun ini (2013).

Adapun yang dapat diidentifikasi sebagai pemisah hubungan antara masyarakat Islam dengan Kristiani yang melekat dengan pemerintah Jerman adalah kesenjangan sosial. Kebanyakan yang miskin dan melakukan kejahatan sosial adalah kaum Muslim dari Eropa Timur dan orang Islam berkulit Hitam dari Maroko. Stereotipe bahwa kejahatan sosial tertentu dilakukan oleh pendatang yang beragama Islam telah berkembang di kalangan masyarakat Indonesia yang beragama Kristen yang bermukim di Jerman. Eksklusivisme dan ekstremisme ideologi tertentu dalam Islam maupun dalam Kristen menjadi pemisah hubungan antara Muslim dan Kristiani. Rumah ibadah umat Islam yang didirikan oleh masyarakat Muslim yang berasal dari daerah tertentu, misalnya dari Turki, Arab dan Afganistan, dalam beribadah dan berkomunikasi menggunakan bahasa daerah asalnya, bukan bahasa Jerman, semakin menunjukkan eksklusivisme masyarakat Islam terhadap masyarakat Jerman yang beragama Kristiani.

Demikian juga ada sayap kanan Kristiani yang duduk dalam perlemen yang menghambat umat Islam membangun rumah ibadah di tempat tertentu di Jerman, demikian juga dengan kelompok sayap kanan Islam yang memerjuangkan ideologi Islam dalam negara Jerman yang mayoritas Kristiani. Selanjutnya faktor pemisah itu datang dari adanya kelompok ekstrem kiri, yakni neo-Nazi yang ada dalam pemerintahan Jerman yang benci terhadap Islam. 
Terkait dengan kepentingan bersama, Suratno menambahkan data bahwa kebiasaan masyarakat Jerman duduk di kafe sembari minum kopi dan bir serta makan makanan tertentu. Bahkan dalam waktu dan situasi tertentu, orang Turki yang berhasil berbisnis dengan membuka restoran kebab (makanan khas Turki) saat ini sudah menjadi tempat berkumpulnya sebagian masyarakat Jerman. Artinya, unsur kepentingan bersama yang dapat disebut unsur bisnis justru mampu mendekatkan hubungan antarumat beragama, Muslim dan Kristiani. Masyarakat yang beragama Kristen berbelanja di warung atau kedai milik umat Islam dan sebaliknya Masyarakat yang beragama Islam belanja di warung atau kedai milik umat Kristen. ${ }^{19}$

Ada cerita lain tentang masyarakat Muslim Turki yang disampaikan oleh masyarakat Kristiani di Frankfurt, bahwa bila ada seorang gadis Turki yang menikah atau berpacaran dengan orang Jerman yang Kristiani, maka tidak segan-segan sang kakak (abang) dari gadis Turki tadi membunuh pacar adiknya yang Kristiani itu. Informasi ini diperoleh dari umat Kristiani yang aktif di Gereja Jemaat Kristus Indonesia di Frankfurt. Peristiwa semacam itu sering terjadi menurut pengakuan mereka (umat Kristiani Indonesia yang sudah lama bermukim di Frankfurt), akan tetapi sikap masyarakat Turki seperti itu tidak diketahui apakah karena anti-Jerman atau antiKristiani. Namun betapa pun juga bagi sebagaian masyarakat Kristiani, hal itu dijadikan jawaban ketika pertanyaan mengarah kepada bagaimana hubungan umat Islam dan Kristiani di Jerman.

19 Keadaan seperti ini terjadi juga di Sumatera Utara: warung nasi "Masakan Padang" atau warung nasi "Masakan Khas Minang" di berbagai daerah Sumatera Utara, terutama di daerah pemukiman Kristiani, yang justru menjadi simbol hubungan Muslim dengan Kristiani. Di daerah-daerah rekreasi di Sumatera Utara, yang mayoritas penduduknya umat Kristiani, terkadang ada di antara mereka yang membuka warung nasi dengan papan nama "Rumah Makan Minang" padahal milik orang Batak yang Kristiani. Terkait dengan "kedai" atau "warung" makanan atau "restoran", maka apabila makanan itu berupa buah-buahan dan sayur-mayur yang belum dimasak, tidak ada masalah siapa yang menjual dan membelinya. Akan tetapi bila makanan yang dijual itu berupa "masakan" atau "sembelihan", bagi sebagian besar masyarakat Muslim akan jadi masalah bila penjualnya adalah Kristiani. Karena soal makanan yang terkait dengan "daging babi" yang menurut umat Islam "haram" dimakan. Demikian juga hewan yang disembelih oleh yang bukan Muslim (Kristen) juga tidak boleh dimakan. Soal pantangan makan daging babi, dan hewan yang disembelih oleh yang bukan Muslim ini dalam batas tertentu menjadi penghalang hubungan harmonis antara Muslim dan Kristiani. 
Bangsa Turki yang ada di Jerman, justru diakui oleh tokoh Kristiani sebagai warga Muslim yang berhubungan sangat baik dengan umat Kristiani, bahkan dibanding dengan Muslim yang pendatang, misalnya dari Maroko, Arab, Pakistan dan dari Indonesia sendiri. Misalkan saja ketika Gereja Jemaat Kristus Indonesia mengundang tokoh-tokoh dan masyarakat Muslim untuk berdialog, yang selalu datang adalah umat Islam Turki. Mereka melakukan upacara Islami di Gereja, azan dan memertunjukkan tari gasing ala sufi. Sementara itu tokoh dan masyarakat Muslim yang tergabung dalam MMI (Masyarakat Muslim Indonesia), tidak pernah datang bila diundang untuk berdialog. ${ }^{20}$ Mengapa umat Muslim di MMI tidak hadir ketika diundang untuk berdialog untuk membangun hubungan harmonis antara Kristiani dan Muslim di Frankfurt. Hal ini dimungkinkan karena dua hal, pertama dalam kelompok MMI, tidak ada tokoh-tokoh Islam yang mumpuni keilmuannya untuk dapat berdialog dengan agama lain; dan kedua ditengarai bahwa akhir-akhir ini berbagai lembaga masyarakat Islam Indonesia yang ada di Jerman telah didominasi oleh kelompok Islam tertentu yang mempunyai paham eksklusif dan fundamentalis yang tidak suka dengan dialog antaragama. $^{21}$

Walaupun dilihat dari jumlah jemaat yang hadir ketika pertama sekali mengunjungi Gereja Jemaat Kristus Indonesia, sekira 50 orang saja, namun lembaga ini memerlihatkan militansinya sebagai persatuan masyarakat Indonesia di Jerman. Mereka terlihat padu, penuh persaudaraan, terbuka, dan masih sangat Indonesia walaupun ada juga di antara mereka yang rindu akan daerah asal mereka di Indonesia, misalnya yang berasal dari Palu, Manado, Makasar, Jawa, Jakarta, Sumatera Utara dan lain sebagainya. Kerinduan itu terlihat ketika kami memerkenalkan diri, berasal dari suku dan daerah tertentu. Tampak respons yang dapat dipahami sebagai luapan rasa rindu itu.

Ketika kami memerkenalkan diri sebagai seorang Muslim, ketika presentase di Gereja tersebut, justru tidak membuat kehangatan mereka berkurang terhadap kami. Sebagian mengidentifikasi sebagai saudara, ketika kami menerangkan asal-usul suku dan daerah kami.

\footnotetext{
${ }^{20}$ Yunita Lasut, Wawancara, Romer, Frankfurt 29 September 2013.

${ }^{21}$ Suratno, Wawancara, Eschborn, Frankfurt 6 Oktober 2013.
} 
Demikian kuatnya ikatan nasionalisme atau primordialisme kesukuan dan kedaerahan apabila kita jauh dari kampung halaman. ${ }^{22}$ Kehadiran kami di Gereja Jemaat Kristus Indonesia di Frankfurt adalah model observasi partisipan yang juga dilakukan di Sumatera Utara. Dengan model ini, didapati kesan bahwa keterbukaan dan ketulusan untuk melakukan hubungan sosial dalam bentuk diskusi dan dialog adalah suatu perekat yang ampuh dalam mendorong terjadinya hubungan yang positif antara masyarakat Muslim dan Kristiani.

Kesadaran nasionalisme bagi masyarakat Indonesia yang bermukim di Frankfurt Jerman juga terlihat ketika mereka berkumpul pada setiap hari Rabu di Konsulat Jenderal Republik Indonesia. Berbagai kegiatan dilakukan bersama, baik yang menganut agama Kristen maupun yang beragama Islam. Setelah acara dilakukan, terjadi kebiasaan makan-makan bersama yang dimulai sekitar pukul 16.00 waktu setempat sampai malam sekitar jam 19.00. Salah satu kegiatan yang dilakukan misalnya membuat acara penyambutan bila ada pejabat dari Indonesia datang berkunjung ke Frankfurt, dengan sangat kompak antara yang Muslim dengan yang Kristiani bekerja sama dalam mendukung kesuksesan acara tersebut. Ada dari mereka yang membawa makanan berupa kue dan roti, serta masakan Indonesia lain. Khusus ketika penelitian ini dilakukan, tepatnya pada hari Rabu tanggal 9 Oktober 2013, Bapak Wakil Menteri Pendidikan dan Kebudayaan Republik Indonesia datang berkunjung ke Frankfurt dalam rangka menghadiri Buchmesse (Pameran Buku Terbesar di Jerman) yang diadakan setiap tahun pada bulan Oktober, dan karena Indonesia direncanakan menjadi panitia penyelenggara pada tahun 2015, maka Wakil Menteri meminta pendapat dan pokok pikiran yang dapat disumbangkan untuk kesuksesan program tersebut dan juga meminta respons terhadap kurikulum 2013 yang akan diterapkan di Indonesia.

\footnotetext{
22 "Rindu Akan Kampung Halaman" adalah istilah yang selalu penulis pakai dalam diskusi dan ceramah tentang "kebangsaan". Bahwa Agama Islam, Kristen Protestan, Katolik, Hindu, Budha, dan Konghucu adalah agama pendatang di Indonesia. Mereka semua adalah "tamu" di negeri Indonesia. Islam berasal dari Arab, Protestan dari Eropa, Katolik dari Roma, Hindu dan Buddha dari India, dan Konghucu dari Cina. Mereka bersatu karena "nasionalisme" di Indonesia. Akan tetapi "rindu" akan kampung halaman masing-masing dengan perwujudan "Arab Oriented" bagi Islam, "Eropa Oriented" bagi Protestan, "Roma Oriented" bagi Katolik, "India Oriented" bagi Hindu dan Buddha dan "Cina Oriented” bagi Konghucu, justru dapat mengikis nilai-nilai nasionalisme Indonesia.
} 
Beberapa orang tokoh yang sudah lama bermukim di Jerman, juga beberapa mahasiswa yang sedang kuliah di Frankfurt baik itu Kristiani maupun Muslim yang saling memberikan pokok pikirannya dengan sangat antusias dan serius sekali. Kecintaan akan nama baik Indonesia itu lebih mengemuka dari pretensi apapun.

Fenomena nasionalisme Indonesia sebagai perekat hubungan Muslim dan Kristiani, tampil dengan wajah yang berbeda ketika berada di Gereja Jemaat Kristus Indonesia, ketika salah seorang Jemaat mengemukakan pendapatnya: "bahwa kami sebagai masyarakat Indonesia yang sudah lama berada di Jerman ini, telah merasakan perubahan yang mengecewakan tentang hubungan Muslim dan Kristiani. Jika sebelum reformasi di Indonesia masyarakat Jerman mengagumi Indonesia karena toleransi antarumat beragamanya sangat baik dan bahkan dalam batas tertentu negara Jerman belajar dengan Indonesia dalam menata hubungan antaragama; maka setelah banyak informasi tentang adanya beberapa pembakaran Gereja hal itu merusak harmonisasi hubungan Muslim dengan umat Kristiani’. ${ }^{23}$

Selanjutnya, berbagai berita tentang kekerasan dan radikalisme agama yang dilakukan oleh masyarakat Islam di Indonesia, termasuk juga di Sumatera Utara terhadap masyarakat Kristiani, sudah menjadi isu yang dapat dijadikan pendorong terciptanya hubungan yang negatif antara masyarakat Muslim dan Kristiani. Akan tetapi ternyata isu tersebut diupayakan juga untuk diatasi oleh beberapa tokoh Kristiani yang penulis kelompokkan kepada pejuang harmonisasi, semisal Pdt. Yunita Lasut yang mewakili agamawan dan Olaf Schumann yang mewakili ilmuan.

Menurut Pdt. Yunita Lasut, memang berkembang isu tentang kekerasan atas nama orang Islam terhadap umat Kristiani di Indonesia yang sampai di Jerman dan mengakibatkan terganggunya perasaan umat Kristiani Indonesia yang berada di Jerman terhadap umat Muslim di Indonesia, akan tetapi kami terutama yang dipersiapkan untuk menjadi pendeta, diminta untuk melakukan penelitian langsung ke berbagai peristiwa yang diissukan itu, apakah benar sebagai kasus hubungan antara Muslim dan Kristiani atau kasus sebagian umat Islam yang fundamentalis atau kasus tertentu yang sesungguhnya tidak melibatkan hubungan antarkedua agama, akan tetapi hanya

\footnotetext{
23 Pernyataan tersebut muncul dari seorang jemaat yang bertanya dalam prosentase kami tentang "Keberagamaan di Sumatera Utara", tanggal 29 september 2013 di Romer Frankfurt.
} 
merupakan kasus perselisihan kecil yang dipolitisasi. Menurut Pdt. Lasut, isu tersebut selalu dibesar-besarkan oleh informasi yang berasal dari kalangan Orientalis. ${ }^{24}$ Lalu ketika isu yang melibatkan terganggunya hubungan harmonis antara Muslim dan Kristiani di Jerman dikonfirmasi dengan Arndt Graf, ia menambahkan bahwa beberapa tokoh dan ilmuan Kristiani termasuk Olaf Schumann juga telah berusaha memberikan penjelasan sejujurnya tentang umat Islam di Indonesia, bahwa teroris dan radikalisme agama bukanlah mewakili umat Islam pada umumnya, hanya sekelompok pihak yang berwawasan sempit dan fanatik yang melakukan hal tersebut. ${ }^{25}$

Akan tetapi, menurut Pdt. Dr. Dietmar Burkhardt, sejak 500 tahun yang lalu di Jerman sudah ada komunitas yang mengedepankan harmoni antar-umat beragama. Uniknya, justru baru dua tahun yang lalu ada lembaga kerukunan yang dibentuk, semisal Rat Der Religion. Pdt. Burkhardt, tidak memberikan penjelasan lebih jauh tentang fenomena itu, apakah terkait dengan suasana politik bahwa umat Islam (Turki) di Jerman, sudah mulai berperan dalam dunia politik atau apakah ada kaitannya dengan semakin pentingnya posisi agama Islam dalam dunia pendidikan di Jerman. ${ }^{26}$

Sejalan dengan upaya masyarakat dan bangsa Jerman untuk melakukan harmonisasi hubungan antaragama, Bernd ${ }^{27}$ mengatakan bahwa sudah sejak ratusan tahun yang lalu Jerman berkepentingan agar hubungan umat beragama, dalam hal ini penganut Yahudi, penganut Islam dan penganut Kristen haruslah hidup rukun agar peradaban bangsa Jerman dapat terbangun dengan baik. Salah satu Penyebab ketidak rukunan hubungan antarumat beragama menurut Bernd adalah karena truth claim. Bernd menceritakan seorang filsuf

\footnotetext{
${ }^{24}$ Dia berasal dari daerah Palu yang tinggal di kalangan minoritas Kristiani di Palu, akan tetapi sudah terbiasa dapat hidup rukun dengan mayoritas Muslim di sana, terutama hubungannya dengan sebuah Pesantren "al-Khairat" yang ada di Kampung halamannya. Yunita Lasut, Wawancara, Römer, Frankfurt 29 September 2013.

25 Arndt Graf, Wawancara, Uni-Westend Frankfurt 30 September 2013.

${ }^{26}$ Dietmar Burkhardt, Wawancara, Gereja JKI Römer Frankfurt 29 September 2013.

27 Bernd Mothes adalah pensiunan militer Berlin, Jerman Timur yang dulu menjadi lawan dari Jerman Barat, di mana kini ia bermukim. Saat ini dia merasa berada di tempat yang salah karena ia tidak mendapatkan uang pensiun sebagai mantan prajurit berpangkat perwira. Ia merupakan alumnus sebuah perguruan tinggi di Leipzig dan menekuni bidang filsafat. Dalam pengakuannya tidak ada agama tertentu yang dianutnya, karena menurutnya agama selalu saja membuat "kacau" dan saling mengklaim "yang paling benar".
} 
bernama Lessing, yang menulis kisah berjudul Nathan the Wise. Kisah Ring Parable dalam drama itu, mengungkapkan bahwa a) perang antaragama menghancurkan diri sendiri, b) konflik antara Yahudi, Islam dan Kristen dalam sejarah telah menghancurkan kemanusiaan, dan c) ketiganya (Yahudi, Kristen dan Islam) telah merusak kemanusiaan. $^{28}$

Menurut Bernd, kerukunan umat beragama akan tercapai dengan empat hal: 1) hiduplah sesuai dengan agama yang kamu anut, 2) Jangan saling mengganggu, 3) Jangan menghina dengan mengatakan bahwa agama kita yang paling benar, dan 4) Saling menghormati satu sama lain.

Adapun agamawan yang dapat menciptakan kerukunan adalah mereka yang berpikir philosophis, karena hanya yang berfilsafat yang dapat menciptakan toleransi dalam pemikirannya. Sementara agamawan yang tidak berpikir philosophis hanya melihat agama sebagai doktrin dan memandang Tuhan sesuai dengan persepsinya sendiri sehingga tidak toleran. ${ }^{29}$

Mengaca kepada sikap dan pandangan Bernd, seorang free thinker, filsuf, dan teolog; yang ternyata sangat mendambakan dan membanggakan kedamaian dan kerukunan yang terjadi dalam masyarakat Jerman, lalu dikaitkan dengan signifikannya penduduk Jerman yang tidak menganut agama tertentu, maka dapat dikatakan bahwa kebebasan untuk tidak menganut agama tertentu di Jerman ini adalah merupakan faktor perekat hubungan Muslim dan Kristiani. Tentulah faktor kebebasan untuk memilih beragama atau tidak beragama yang terjadi di Jerman ini, tidak didapati kasusnya di Sumatera Utara, karena terkait dengan konstitusi negara Indonesia yang menganut falsafah Pancasila, bahwa setiap masyarakat dan anak bangsa mestilah menganut agama dan kepercayaan tertentu. Itu pun tidak boleh lebih dari satu agama atau lebih dari satu kepercayaan yang dianut pada saat yang sama.

Masyarakat Jerman bukan hanya dibebaskan beragama oleh konstitusinya bahkan tidak beragama pun dapat kebebasan. Konstitusi negara Jerman yang demikian itulah yang membuat berbagai masyarakat dapat hidup dengan bebas di Jerman. Demikian juga berbagai aliran, mazhab, dan bahkan mungkin sekte dapat hidup dan berkembang di Jerman.

28 Bernd Mathes, Wawancara, Rosdorf Bruchkobel, Jerman 29 September 2013.

${ }^{29}$ Ibid., 5 Oktober 2013. 
Namun demikian hidup dan berkembangnya berbagai aliran, mazhab dan sekte keagamaan itu tentu tidak boleh melampaui batasan hukum dan konstitusi yang menjamin ketenteraman dan hak asasi seluruh masyarakat, sehingga jika terdapat suatu aliran, mazhab, dan sekte agama tertentu yang melakukan aksi atau gerakan yang dapat dipandang sebagai sesuatu yang melanggar konstitusi, maka secara tegas pemerintah menghukum dan mengusir gerakan tersebut dari negara Jerman. Hal seperti disebutkan itu pernah terjadi pada kelompok-kelompok Islam fundamentalis semisal Hizbut Tahrir yang dilarang pada tahun 2002, Islamic Kheliphet tahun 2003 dan Salafi Iere Vogel yang dilarang pada tahun 2012. ${ }^{30}$

Kebebasan beragama yang disertai hukum yang kuat dan tegas dalam melindungi masyarakat di Jerman membuat beberapa aliran, mazhab dan sekte keagamaan tertentu tidak merasa khawatir hidup dan berkembang di negara Jerman. Walaupun demikian, didengar informasi bahwa Kelompok Ahmadiyah yang ada di Jerman, terkadang tidak mau menyebutkan identitasnya terhadap masyarakat Islam yang berasal dari Indonesia, karena merasa khawatir, kalau-kalau masyarakat Islam Indonesia memusuhi mereka akibat fatwa Majelis Ulama Indonesia bahwa Ahmadiyah adalah aliran sesat dan bahkan keluar dari Islam. ${ }^{31}$

Majelis-majelis Agama sebagaimana yang terdapat di Indonesia, tidak ada di Jerman. Kalaupun ada Majelis Fatwa Eropa, kata Suratno, fungsinya hanya untuk menyamakan persepsi tentang kegiatan umat Islam di seluruh Eropa dan termasuk juga di Jerman, bukan sebagaimana Majelis Ulama di Indonesia, yang fungsinya terkesan menjaga agama, sebagaimana pengakuan Prof. Dr. H. Ramli Abdul Wahid, MA. dan telah mengambil kebijakan dengan mengatakan sesat beberapa aliran dan mazhab serta paham umat Islam yang tidak mengikuti pemahaman mainstream umat Islam Indonesia, semisal Nahdlatul Ulama, Muhammadiyah, al-Washliyah, dan sebagainya.

Akan tetapi malah sebaliknya, di Jerman, justru pandangan MUI seperti yang dipahami Prof. Ramli, telah menimbulkan reaksi negatif, bagi masyarakat Indonesia yang ada di Jerman, terutama bagi mereka yang hadir di pertemuan Reboan di KJRI pada tanggal 16 Oktober 2013. Sebagian masyarakat Kristiani yang hadir dalam pertemuan Reboan merasa terganggu dengan kebijakan MUI, yang menurut

\footnotetext{
${ }^{30}$ Suratno, Wawancara, Eschborn, Frankfurt 6 Oktober 2013.

${ }^{31}$ Heny, Wawancara, Eschborn, Frankfurt 12 Oktober 2013.
} 
mereka telah melakukan pelanggaran terhadap Konstitusi dan UUD 1945 Pasal 29 tentang kebebasan beragama. Tokoh-tokoh Kristiani yang senior dan sudah lama di Frankfurt, mengatakan bahwa dulu (sebelum Reformasi dan bahkan sebelum adanya MUI), justru umat beragama di Indonesia hidup dengan damai dan rukun, akan tetapi justru belakangan ini, justru konflik dan ketidakrukunan itu disebabkan oleh adanya fatwa-fatwa dari MUI, misalnya tentang Ahmadiyah. Kerusuhan dan pembakaran masjid milik Ahmadiyah itu akibat Fatwa Majelis Ulama Indonesia terhadap Ahmadiyah. ${ }^{32}$

Pandangan masyarakat Kristiani di Jerman terhadap Kebijakan MUI yang mengatakan sesat aliran dan mazhab serta pemahaman keagamaan dalam masyarakat Islam, justru dapat dipandang melanggar konstitusi dan dapat dihukum bila hal itu diterapkan di Jerman. Akan tetapi Prof. Ramli justru berargumentasi sebaliknya, bahwa kebijakan MUI terhadap Ahmadiyah adalah urusan rumah tangga dalam agama Islam sendiri dan orang lain (maksudnya orang Kristiani) apabila turut campur, hal itu dapat dikategorikan sebagai melakukan penodaan terhadap agama. ${ }^{33}$ Hal yang demikian bisa dijadikan tuduhan bahwa telah terjadi intervensi pihak Kristiani terhadap hak asasi umat Islam dalam melaksanakan keyakinannya.

Dari kasus yang terjadi di KJRI Frankfurt am Main, Jerman ini dapatlah dikatakan bahwa perbedaan pemahaman tentang kebebasan dan hak asasi dapat menjadi faktor pemisah; umpamanya karena kecurigaan sikap umat Kristiani terhadap MUI dalam kasus Ahmadiyah, yang menuduh MUI melanggar Konstitusi Indonesia tentang kebebasan beragama dan hak asasi manusia; sebaliknya pihak Muslim yang diwakili MUI merasa bahwa pihak Kristiani sudah mengintervensi pribadi Muslim yang terkesan membela Ahmadiyah yang telah menjadi aliran yang melakukan penodaan terhadap agama Islam.

Dalam sebuah diskusi khusus yang kami lakukan dengan masyarakat Kristiani di Jerman, yang dihadiri oleh umat Katolik dan Protestan, diperoleh penjelasan bahwa umat Kristiani memahami MUI mewakili umat Islam Indonesia dan bahkan mewakili teologi umat Islam di dunia, sehingga kebijakan MUI merepresentasikan wajah Islam seluruhnya. Mereka terkejut dan seolah baru tersadar bahwa MUI adalah majelis agama yang fungsi dan tugasnya sama

\footnotetext{
32 Rusydin Sumbayak, Wawancara, Rosdorf Bruchkobel, Jerman 17 Oktober 2013.

${ }^{33}$ Ramli Abdul Wahid, Wawancara, Abu Dhabi 19 Oktober 2013.
} 
dengan KWI (Konferensi Waligereja Indonesia) dan PGI (Persekutuan Gereja-gereja Indonesia). Anggapan bahwa MUI mewakili teologi Islam dunia oleh masyarakat Jerman, bisa saja lahir karena melihat peran MUI yang terkesan sentral yang terkadang mampu memicu kekerasan atas nama agama di Indonesia. Hal ini menguatkan anggapan bahwa MUI adalah pemegang otoritas keagamaan dalam Islam karena pengaruh kebijakannya begitu kuat. ${ }^{34}$

Sementara itu, EKHN sebagai yang mewakili Majelis Agama Kristen di Jerman, fungsi dan perannya sama saja dengan Majelis Agama Kristiani, semisal KWI dan PGI di Indonesia; utamanya terkait dengan kebijakan terhadap berbagai aliran, mazhab dan bahkan sekte yang ada dalam ke-Kristen-an. Menurut Pdt. Bichauf bahwa dalam ke-Kristen-an terdapat juga berbagai aliran yang berbeda dari Gereja Besar, dan Gereja-gereja kecil ini sulit dikontrol dan dikendalikan, baik kegiatannya maupun pemahamannya, dan dilihat dari sudut pandangan hubungannya dengan umat Islam, maka Gereja Besar lebih baik dibanding dengan Gereja-gereja Kecil terhadap umat Islam. Bahkan hubungan Gereja-gereja Kecil dalam bentuk aliranaliran itupun hubungannya kurang baik dengan Gereja Besar. ${ }^{35}$

Menurut Pdt. Dietmar Burkhardt, bahwa munculnya berbagi aliran atau denominasi bahkan sekte dalam Kristiani, tidaklah menjadi masalah karena hal itu suatu dampak dari kehidupan masyarakat Jerman yang sekuler di satu sisi akan tetapi kepedulian negara terhadap agama di sisi yang lain. Negara yang tidak mengintervensi urusan agama membuat agama dapat saja tumbuh berkembang sesuai kebutuhannya, termasuk mewujud dalam bentuk aliran, mazhab, denominasi, dan sekte. Sejalan dengan itu, justru perhatian Negara terhadap agama baik Katolik maupun Kristen Protestan, bahkan Islam dan Yahudi, diwujudkan dalam hal penegakan hukum yang dapat melindungi hak rakyat untuk mengembangkan pemahanan dan keyakinan serta mengaplikasikan ajaran agamanya sesuai dengan yang diyakininya selama tidak melanggar hak-hak orang lain.

34 MUI sebenarnya hanya sebuah organisasi keagamaan yang berdiri berdasarkan undang-undang keormasan dan memiliki kedudukan yang sama dengan organisasi kemasyarakatan lainnya, seperti Lembaga Swadaya Masyarakat, dan lain sebagainya. Akan tetapi, besarnya peranan MUI, bahkan pada level tertentu mempengaruhi kebijakan negara dan berhasil membentuk opini publik bahwa lembaganya memiliki otoritas penuh dalam menentukan berbagai kebijakan yang terkait dengan keberagamaan umat Islam.

${ }^{35}$ Bichauf, Wawancara, Gereja JKI, Römer, Frankfurt 13 Oktober 2013. 
Konsili Vatikan II adalah pembuka jalan bagi umat Katolik berhubungan dengan agama lain, termasuk juga kepada Kristen Protestan dan aliran Karismatik yang ada dalam Katolik, semisal Ordo Carmel.

Terkait dengan adanya kelompok agama yang cenderung ekstrem dan fundamentalis, semisal karismatik dalam Kristen, dan FPI dalam Islam. Grover mengungkapkan bahwa sesungguhnya umat Kristiani senang kalau ada umat Islam yang menolak berdirinya banyak gereja di Indonesia, karena yang berlomba-lomba membangun gereja sebanyak-banyaknya di Indonesia itu, bukanlah Gereja Mainstrem tetapi mereka yang Karismatik. Pernyataan ini mendukung hipotesa bahwa, pecah di dalam agama secara intern, akan baik hubungannya ke luar, kepada agama lain secara eksternal. Artinya, munculnya berbagai aliran dalam suatu agama menjadi simbol terjadinya konflik internal agama, akan tetapi secara bersamaan dapat juga memberi harapan baiknya hubungan kepada agama lain. ${ }^{36}$ Beberapa hal yang dapat disebut sebagai perekat dan pemisah hubungan MuslimKristiani juga terungkap dalam diskusi kami. Sepertinya hanya konfirmasi saja. Misalnya saling curiga, missi dan dakwah, adalah faktor pemisah. Ketulusan, kerja sama, saling membantu, kepedulian atas dasar kemanusiaan, adalah faktor perekat.

\section{Penutup}

Penelitian yang dilakukan di Frankfurt am Main, Jerman ini sifatnya lebih sebagai konfirmasi atau penguatan terhadap hasil penelitian yang sudah ditemukan di Sumatera Utara. Adapun yang sama sekali berbeda adalah tentang eksistensi agama dalam negara, dan Indonesia yang mayoritas Muslim dengan Jerman yang Mayoritas Kristiani.

Jerman sebagai tempat lahirnya Kristen Lutheran, dan Max Weber dengan teori Sosilogi Agamanya, juga memberi inspirasi yang baik untuk memberi ruh bagi penelitian tentang Hubungan Muslim dan Kristiani yang terjadi di Sumatera Utara. Teori Weberian yang mengatakan bahwa: "agama memberi pengaruh terhadap kehidupan sosial" terlihat jelas pada faktor pemisah; sedangkan pada faktor perekat justru faktor agama terlihat samar-samar berada dibalik adat dan budaya, serta kearifan lokal maupun dalam bentuk kesadaran atas persaudaraan sebangsa dan bahkan sesama umat manusia; ditambah

36 Diskusi terfokus tanggal 10 Oktober 2013 di Rosdorf Bruchkobel bersama Mr. Grover Rondonuwu, suami Pdt. Yunita Lasut. 
lagi faktor luar berupa Konstitusi Negara yang tegas dan kuat dalam memelihara harkat dan martabat serta hak asasi manusia.

Akan tetapi isu tentang pembakaran Gereja dan Peraturan Bersama Dua Menteri (PB2M) No. 9 dan No. 8 tahun 2006 yang menyulitkan pembangunan Gereja di Indonesia, serta Fanatisme dan Eksklusivisme sebagian kelompok umat Islam pendatang, seperti dari Arab, Afghanistan, Tunisia, Maroko dan sebagian dari Indonesia, dapat dijadikan penyebab hubungan negatif antara Kristiani dan Muslim di Jerman.

\section{Daftar Rujukan}

Aritonang, Jan S. Sejarah Perjumpaan Kristen dan Islam di Indonesia. Jakarta: BPK Gunung Mulia, Cet. Ke-3 2006.

Balondo, Daniel. Wawancara. Toraja 25 September 2013.

Bern. Wawancara. Bruchkobel, Jerman 5 Oktober 2013.

Bichauf. Wawancara. Gereja JKI, Römer, Frankfurt 13 Oktober 2013.

Burkhardt, Dietmar. Wawancara. Gereja JKI Römer Frankfurt 29 September 2013.

Dasuha, Juandaha RP. Sejarah Seratus Tabun Pekabaran Injil di Simalungun, 3 September 1903-2003. P. Siantar: Kolportase GKPS dll., 2003.

Graf, Arndt. Wawancara. Uni-Westend Frankfurt 30 September 2013. Hadiluwih, Subanindyo. Konflik Etnis di Indonesia: Suatu Kajian Kes di Bandaraya Medan. Medan: USU Press, 2008.

Heny. Wawancara. Eschborn, Frankfurt 12 Oktober 2013.

Hutauruk, J.R. Kemandirian Gereja. Jakarta: BPK Gunung Mulia, 1992.

Irwansyah. "Interaksi Sosial Muslim-Kristiani di Sumatera Utara:

Studi tentang Hubungan Keduanya di Pemukiman". Tsaqafah: Jurnal Peradaban Islam, Vol. 10, No. 2, 2014.

Lasut, Yunita. Wawancara, Römer, Frankfurt 29 September 2013.

Mathes, Bernd. Wawancara. Rosdorf Bruchkobel, Jerman 29 September 2013.

----. Wawancara. Rosdorf Bruchkobel, Jerman 5 Oktober 2013.

Meuraxa, Dada. Sejarah Kebudayaan Suku-suku di Sumatera Utara. Medan: Sasterawan, 1973.

Purba, Kenan., dan Purba, J.D. Sejarah Simalungun. Jakarta: Bina Budaya Simalungun, 1995.

Marsden, Williem. Sejarah Sumatera. Bandung: Remaja Rosdakarya, 1999. 
Sumbayak, Rusydin. Wawancara. Rosdorf Bruchkobel, Jerman 17 Oktober 2013.

Suratno (Pengurus NU Jerman). Wawancara. Eschborn, Frankfurt 6 Oktober 2013.

----. Wawancara. Eschborn, Frankfurt 6 Oktober 2013.

----. Wawancara. Goethe Universitat, Frankfurt Jerman 13 Oktober 2013.

Wawancara. Trier, Jerman 8 Oktober 2013.

Wahid, Ramli Abdul. Wawancara. Abu Dhabi 19 Oktober 2013. 